\title{
FABRICATION OF PLATINUM NANOPARTICLE/BORON NITRIDE QUANTUM DOTS/6-METHYL-2-(3- HYDROXY-4-METHOXYBENZYLIDENAMINO)-BENZOTHIAZOLE (ILS) NANOCOMPOSITE FOR ELECTROCATALYTIC OXIDATION OF METHANOL
}

\author{
MURAT BEYTUR * \\ Kafkas University, Faculty of Science and Letters, Department of Chemistry, Kars, Turkey.
}

\begin{abstract}
Fuel cells have important applications in recent decades due to high-energy demands, fossil fuel depletions and environmental pollution throughout world. A fuel cell is an electrochemical cell that converts a source fuel into an electrical current. It generates electricity inside a cell through reactions between a fuel and an oxidant, triggered in the presence of an electrolyte. In this study, preparation of Platinum nanoparticle (PtNPs)/boron nitride quantum dots (BNQDs)/6-methyl-2-(3-hydroxy4-methoxybenzylidenamino)-benzothiazole (ILs) nanocomposite (PtNPs/BNQDs/ILs) has been made. Afterwards, using various equipment and methods, characterization has been carried out. These equipment and methods are as follows: Transmission Electron Microscope, Scanning Electron Microscope, X-Ray Photo Electron Spectroscopy, Energy-Dispersive X-Ray Spectroscopy and X-Ray Diffraction Method. The catalyst developed on PtNPs/BNQDs/ILs has proven to be costeffective. Moreover, the PtNPs/BNQDs/ILs nanocomposite has achieved a higher peak for the current oxidation of methanol, when compared to BNQDs/ILs and ILs. Therefore, this catalyst has a better catalytic activity.
\end{abstract}

Keywords: Fuel cell, Polyoxometalate, Ionic liquid, Electrochemistry.

\section{INTRODUCTION}

Schiff bases having the azomethine group or $\mathrm{HC}=\mathrm{N}$ imine bonds are prepared by the condensation between amines and actived carbonyl compounds [1,2]. Schiff-bases have been extensively studied due to their applicability in various areas such as biological [3-6], chemical [7-9], industrial [10] and pharmaceutical applications $[11,12]$. Schiff bases derivatives have recently increased studies related to corrosion inhibitors [13], optical sensors [14], highly selective polymer membrane electrodes [15], semiconducting [16], therapeutic properties, highly thermal stability, modern technology (nonlinear optical materials) [17], various coordination, homogenous catalysis [17, 18] and biological probes [19]. Because of well-synthesized structures, all properties make them and derivatives useful in organic structure in electronic and opto-electronic devices, pharmaceutical products or thermo-durable materials [20, 21]. They are widely used in pharmaceutical industry because of their valuable clinical and pharmacological properties [22]. The azomethine moiety plays a very important role in biological active systems [23]. It has also been shown to exhibit a wide range of biological activities including antibacterial [5], antitumor [24], antiproliferative [25], antimalarial [26], antiinflammatory [27] and antioxidant [6, 9, 28]. Thanks to the redox activity of metal-Schiff base compounds, Schiff base adsorption on the electrodes'surface areas result in electro-reduction and electro-oxidation reactions more strongly catalysed [29]. There have been many recent studies on methanol as a green power source that has decent activity for a fuel cell system $[30,31]$. Today's world is facing tough challenges increasing energy demand worldwide despite conventional power sources being insufficient. This provides motivation for the scientists to develop new technologies for clean energy. Technologies for clean energy such as fuel cells, super capacitors and high energy density batteries are now receiving more research efforts due to this [3234]. Fuel cell usage in energy generation has great flexibility as it can be used with many fuels and it is currently a very important method in research field [35, 36]. Direct-methanol fuel cells in particular are getting more and more popular since their specific energy density is high and methanol fuel can be converted properly even at low temperatures [36]. Hexagonal boron nitride nanosheets as white graphene carrying the feature of being two-dimensional materials are currently used in drug delivery, bioimaging, sensor applications and catalysing [37, 38]. 2D-hBN nanosheets have a desirable feature; their band-gap is wide. Thanks to this, they are good transparents when located in visible or IR areas. Moreover, thanks to the surface and conductivity properties, these materials are used successfully in electrochemical sensors [39, 40]. 2D-hBN nanosheet application is also present in the loading of metal nanoparticles [41]. Layered hexagonal boron nitride nanosheets' size reduction to less than $10 \mathrm{~nm}$ can result in the obtaining of BNQDs. They have good dispersibility and fluorescence features and that is because quantum confinement and edge effects $[42,43]$ and can be used in biological and optoelectronic applications [44, 45]. In the literature, Copper nanodomes (CuNDs) were developed by combining of soft lithography and nanosphere lithography. The if/ib ratios were found to be 1.18 and 2.00 for the bulk $\mathrm{Cu}$ and $\mathrm{Cu}$-NDs electrodes. Hence, we can say that GQDs/fMWCNTs/GCE in this study has more effective poisoning-tolerance for DMFCs in comparison with bulk $\mathrm{Cu}$ and $\mathrm{Cu}-\mathrm{NDs}$ electrodes [46]. Graphene oxide and core-shell nanoparticle based modified electrodes were fabricated for methanol oxidation [47-50].

First step herein was the synthesis and characterization of PtNPs/BNQDs/ILs nanocomposite. This is followed by the preparation of an effective catalyst based on the PtNPs/BNQDs/ILs nanocomposite. This material's purpose is that it will be applied in direct methanol fuel cells, abbreviated as "DMFCs". The obtained catalyst's characterization was made via X-Ray Diffraction (XRD), EnergyDispersive X-Ray Spectroscopy (EDX), Scanning Electron Microscope (SEM), X-Ray Photo Electron Spectroscopy (XPS) methods. Modification of glassy carbon electrode (GCE) surfaces performed using OLs, BNQDs/OLs and PtNPs/BNQDs/OLs nanocomposite. An infrared heat lamp was used. The characterization of developed surfaces was performed via Chronoamperometry (CA) and Cyclic Voltammetry (CV) and those determine how suitable they are for application in DMFCs.

\section{EXPERIMENTAL}

\subsection{Materials and Instrumentation}

All of the solvents and chemical reagents used were obtained by purchasing from Merck AG (Germany). Determination of melting temperature was formed inside an open glass capillary and a Stuart melting point SMP30 apparatus was utilized. It was uncorrected. ALPHA-P BRUKER FT-IR spectrometer was utilized to get the IR spectra. Recordings of ${ }^{1} \mathrm{H}$ and ${ }^{13} \mathrm{C}$ NMR spectra were carried out in deuterated dimethyl sulfoxide. As internal standard, TMS was used. A Bruker Ultrashield Plus Biospin spectrometer was used. For ${ }^{1} \mathrm{H}$, it was run at 400 $\mathrm{MHz}$ and for ${ }^{13} \mathrm{C}$ it was run at $100 \mathrm{MHz}$. All of the electrochemical experiments, which were cyclic voltammetry and chronoamperometry, were carried out by utilizing out IviumStat (U.S) with C3 cell stand. Morphology investigation for the nanocomposite was carried out by JEOL 2100 HRTEM (JEOL Ltd., Tokyo, Japan). For the SEM images ZEISS EVO 50 analytic microscope (Germany) was used. For the XPS analysis, PHI 5000 Versa Probe (FULVAC-PHI, Inc., 
Japan/USA) model was used, which had monochromatized Al Ka radiation $(1486.6 \mathrm{eV})$. In the measurement of X-ray diffraction, a Rigaku X-ray diffractometer was used.

\subsection{Preparation of ILs}

First step was the dissolving of $0.01 \mathrm{~mol} 2$-amino-6-methylbenzothiazole in 20 $\mathrm{ml}$ acetic acid. Then treatment with 0.01 mol 3-hydroxy-4methoxybenzaldehyde has been conducted. Afterwards evaporation took place at $50-55{ }^{\circ} \mathrm{C}$ in vacuo. After recrystallization carried out a few times for the residue from ethanol, a pure compound 6-methyl-2-(3-hydroxy-4methoxybenzylidenamino)-benzothiazole (ILs) as green colour crystals. Yield: $2.95 \mathrm{~g}(98 \%)$; mp: $86^{\circ} \mathrm{C}$; IR $\left(\mathrm{KBr}, v, \mathrm{~cm}^{-1}\right): 3288(\mathrm{OH}), 1603,1575(\mathrm{C}=\mathrm{N}), 807$ (1,4-disubstituted benzenoid ring); ${ }^{1} \mathrm{H}$ NMR (400 MHz, DMSO-d $\left.\mathrm{d}_{6}\right): \delta 2.31$ (s, $\left.3 \mathrm{H}, \mathrm{CH}_{3}\right), 3.88\left(\mathrm{~s}, 3 \mathrm{H}, \mathrm{OCH}_{3}\right), 7.02(\mathrm{~d}, 1 \mathrm{H}, \mathrm{ArH} ; J=7.20 \mathrm{~Hz}), 7.12$ (d, $1 \mathrm{H}, \mathrm{ArH}$; $J=8.40 \mathrm{~Hz}), 7.23(\mathrm{~d}, 1 \mathrm{H}, \mathrm{ArH} ; J=8.00 \mathrm{~Hz}), 7.30(\mathrm{~s}, 1 \mathrm{H}, \mathrm{ArH}), 7.44(\mathrm{~s}, 1 \mathrm{H}, \mathrm{ArH})$, $7.79(\mathrm{~d}, 1 \mathrm{H}, \mathrm{ArH} ; J=6.80 \mathrm{~Hz}), 8.98(\mathrm{~s}, 1 \mathrm{H}, \mathrm{N}=\mathrm{CH}), 9.79(\mathrm{~s}, 1 \mathrm{H}, \mathrm{OH}) ;{ }^{13} \mathrm{C} \mathrm{NMR}$ (100 MHz, DMSO-d $\left.\mathrm{d}_{6}\right): \delta 20.68\left(\mathrm{CH}_{3}\right), 56.78\left(\mathrm{OCH}_{3}\right), 111.61,117.41,120.77$, 121.92, 126.39, 127.86, 129.88, 134.65, 147.07, 165.69, 166.14, 170.73 (Ar-C), $153.37(\mathrm{~N}=\mathrm{CH}), 191.37$ (benzothiazole $\mathrm{C}_{2}$ ).

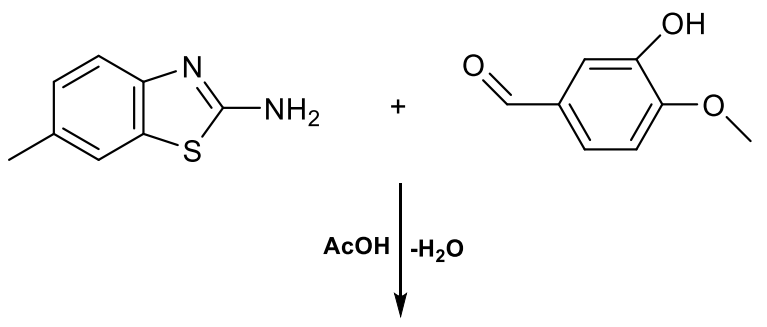<smiles>COc1ccc(/C=N/c2nc3ccc(C)cc3s2)cc1O</smiles>

Scheme 1. Synthesis route of compound ILs

\subsection{Synthesis of BNQDs, BNQDs/ILs and PtNPs/BNQDs/ILs}

Protocol's first performing was according to the literature [51] and 2D hexagonal boron nitride (2D-hBN) nanosheets were obtained [51]. Following degasification of $2 \mathrm{D}-\mathrm{hBN}$ with $\mathrm{N}_{2}$ for 30 minutes, oxygen was removed. Under solvothermal conditions, dispersions were decanted into autoclave running at 180 ${ }^{\circ} \mathrm{C}$. They stayed in the autoclave for 10 hours. After autoclaving, cooling at room temperature took place. Centrifugation was performed at $10000 \mathrm{rpm}$ and the supernatant was obtained as BNQDs [40]. 6-methyl-2-(3-hydroxy-4methoxybenzylidenamino)-benzothiazole for ILs. It was in a dissolved form and solvent contained ethanol, which had a concentration of $2 \mathrm{mg} \mathrm{mL}^{-1}$. Well-mixing of ILs was conducted with BNQDs at a 1:1 volume ratio and time was 2 hours (BNQDs /ILs). Then $1 \mathrm{mM} \mathrm{K2PtCl} 4$ solutions were added into the BNQDs /ILs solution $\left(1.0 \mathrm{mg} \mathrm{mL}^{-1}\right)$.

\subsection{Electrode preparations and electrochemical measurements}

Preparation of the glassy carbon electrodes was in accordance to our report [52]. At the last stage suspensions of $2 \mathrm{D}-\mathrm{hBN}$ and BNQDs that were $10 \mu \mathrm{L}$ were dropped to the clean surface after which solvent was removed and the solvent was removed under an infrared heat lamp. Next step was the electrocatalytic oxidation of $0.5 \mathrm{~mol} \mathrm{~L}^{-1}$ methanol on ILs, BNQDs/ILs and PtNPs/BNQDs/ILs. $0.1 \mathrm{~mol} \mathrm{~L}^{-1} \mathrm{HClO}_{4}$ used and $\mathrm{CV}$ was 0.0 to $+1.2 \mathrm{~V}$. Reference electrode was $\mathrm{Ag} / \mathrm{AgCl}$. Counter electrode was $\mathrm{Pt}$ wire electrodes. In an aqueous solution with $0.1 \mathrm{M} \mathrm{HClO} 4$ and that was saturated with $\mathrm{O}_{2}$, linear sweep voltammograms (LSV) were obtained. Prior to each of the measurements 30 minutes of $\mathrm{O}_{2}$ bubbling was made to electrolyte. $\mathrm{O}_{2}$ flow was maintained over the electrolyte during measurement. This was performed to make sure that there was constant saturation of $\mathrm{O}_{2}$. Also, DMCF measurements were performed at a temperature of $25^{\circ} \mathrm{C}$. The measurements and voltammograms were performed in an insulation cabinet for avoiding temperature and pressure fluctuation effect on the sensor response.

\section{RESULTS AND DISCUSSION}

\subsection{Characterization}

Bulk boron nitride's XRD pattern can be seen in Figure 1 curve a while Figure 1 curve $\mathrm{b}$ shows that for 2D-hBN nanosheets. Bulk boron nitride's XRD pattern demonstrates characteristic diffraction peaks. Those correspond to the planes (100), (101) and (102) [53]. In the XRD pattern of 2D-hBN nanosheets, these characteristic diffraction peaks disappeared. Despite that, (002) plane of boron nitride is still there [54].

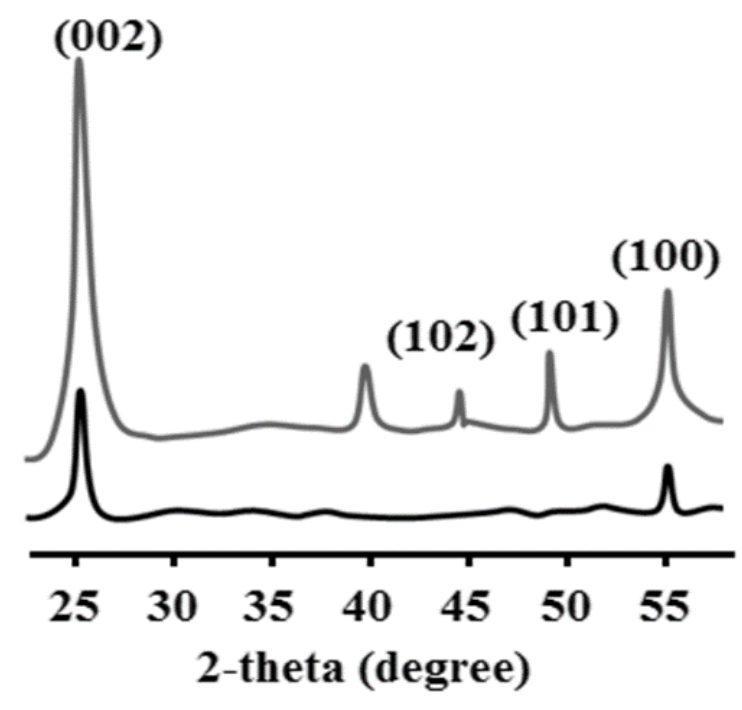

Figure 1. XRD pattern (A) of bulk boron nitride (curve a) and 2D-hBN nanosheets (curve b).

Boron nitride's bulk structure is confirmed by its SEM image, which is at Figure 2A. Bulk structure demonstrates irregular morphology, agglomeration and various boron nitride dimensions are visible. After ultrasonication was applied to bulk born nitride, 2D-hBN nanosheets were obtained. Figure 2B suggests 2D-hBN nanosheets formation. Since 2D-hBN nanosheets have lateral sizes while bulk boron nitride is larger, particle thickness goes down. In the Figure 2C, TEM image of BNQDs can be seen. This means the BNDQs obtained show good dispersion and lateral sizes are uniform. Lateral sizes' average values are seen as $4.1 \pm 0.2 \mathrm{~nm}$ (Figure 2C). Figure 2D confirms that there are PtNPs on nano-linked and nanopore structure with cross-linking. Analysis of their structures concluded a 5-10 nm average diameters PtNPs.
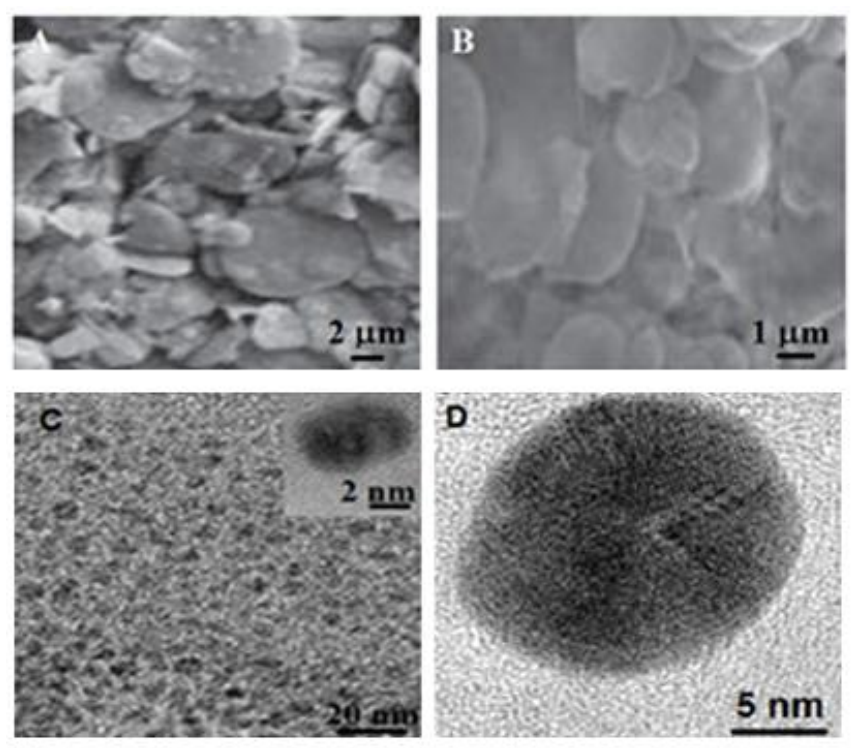

Figure 2. SEM images of (A) bulk boron nitride; (B) 2D-hBN nanosheets; (C) TEM image of BNQDs; (D) TEM images of PtNPs/BNQDs/ILs. 

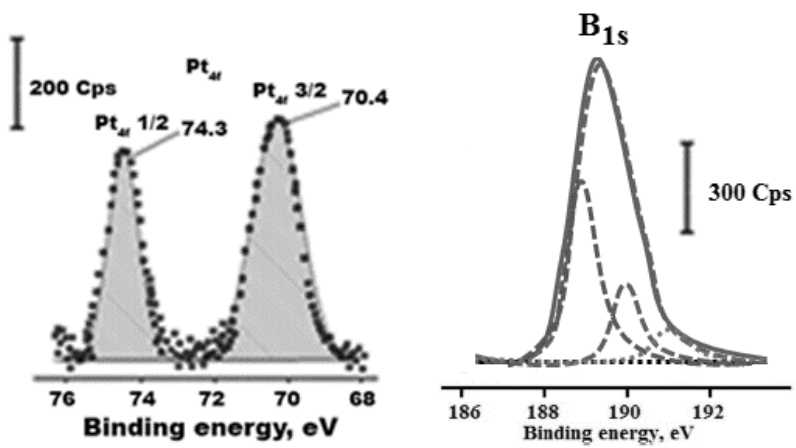

Figure 3. XPS core-level spectrum of Pt4f and B1s for PtNPs/BNQDs/ILs

In Figure 3, a narrow region XPS spectra for PtNPs/BNQDs/ILs nanocomposite can be seen. For Pt $4 \mathrm{f}$ area doublet $4 \mathrm{f} 1 / 2$ signal and $4 \mathrm{f} 3 / 2$ signals took the values of 74.3 and $70.4 \mathrm{eV}$, respectively. This means that there exists PtNPs on BNQDs/ILs. The peak located at 190.4, 189.2 and $189.8 \mathrm{eV}$ in the B1s narrow region is corresponded to boron in Figure 3.

Figure 4 showed the impedance plot (Nyquist diagram) of the bare GCE and different modified electrodes. The inset of Figure 4 showed the experimental data obtained that are fitted to standard Randles equivalent circuits for PtNPs/BNQDs/ILs/GCE surface analysis, which comprizes the solution resistance $\left(R_{s}\right)$, the charge transfer resistance $\left(R_{c t}\right)$ and the constant phase element (CPE). The experimental impedance values are matched with Randles equivalent circuit simulation using Gamry software (EIS 600 Electrochemical Impedance Spectroscopy Software). Charge transfer resistance (Rct) values are $180 \mathrm{ohm}$ (curve $\mathrm{c}$ of bare GCE), $70 \mathrm{ohm}$ (curve b of BNQDs/GCE) and $30 \mathrm{ohm}$ (curve a of PtNPs/BNQDs/ILs/GCE), respectively by EIS spectra (Figure 4). Hence, the highest conductivity were obtained by PtNPs/BNQDs/ILs/GCE. Two obvious reasons explain the optimal electrochemical responses which are caused by PtNPs/BNQDs/ILs/GCE.

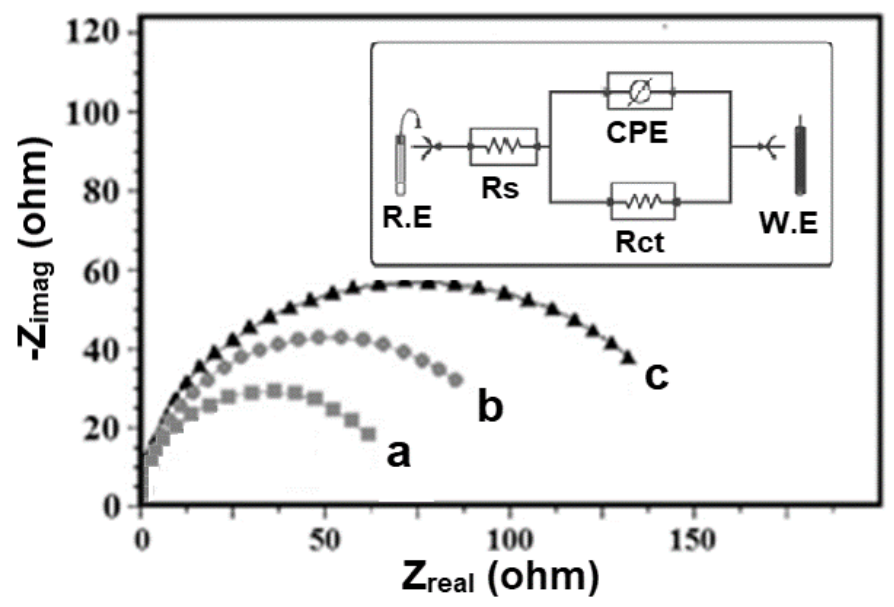

Figure 4. EIS response at (a) PtNPs/BNQDs/ILs, (b) BNQDs/GCE, (c) bare GCE (Frequency range: $100000-0.1 \mathrm{~Hz}$, Wave amplitude: $15 \mathrm{mV}$ and formal potential: $0.172 \mathrm{~V})$; In the presence of $1.0 \mathrm{mM}[\mathrm{Fe}(\mathrm{CN}) 6]^{3-}$ containing $0.1 \mathrm{M}$ $\mathrm{KCl}$. Inset : the Randles equivalent circuit.

3.2. Electrochemical studies by using ILs, BNQDs, BNQDs/ILs, and PtNPs/BNQDs/ILs

Rotating disk electrode (RDE) voltammograms were performed. They are used for the investigation of electrocatalytic activities happening at the nanomaterials for $0.5 \mathrm{M}$ methanol by $\mathrm{CV}$ in $0.1 \mathrm{~mol} \mathrm{~L}^{-1} \mathrm{HClO}_{4}$ at $50 \mathrm{mV} \mathrm{s}^{-1}$ (Figure 5). For PtNPs/BNQDs/ILs, current peak is seen as $10.5 \pm 0.02 \mathrm{~A} \mathrm{~cm}^{-2}$, which was acquired while making a forward anodic scan (If), which had a potential of 0.79 $\mathrm{V}$. On the other hand, the reverse scan $(\mathrm{Ib})$ showed a current peak that was $4.05 \pm 0.02 \mathrm{~A} \mathrm{~cm}^{-2}$ at $0.58 \mathrm{~V}$. Table 1 demonstrates the methanol oxidation performances of ILs, BNQDs, BNQDs/ILs and PtNPs/BNQDs/ILs. PtNPs/BNQDs/ILs' forward peak was 1.15 and 1.48 times higher than
BNQDs/ILs, BNQDs and ILs, respectively. In addition to that, a control experiment was conducted. Black curve in Figure 5 demonstrates its results. According the black curve, during the reverse and forward anodic scans showed no current peaks. This means that the vast increase in the methanol oxidation can be attributed to surface that is highly active and BNQDs/ILs and PtNPs' electronic interactions being efficient. Surface area of ILs/GCE was $0.168 \mathrm{~cm}^{2}$ of BNQDs/GCE it was $0.215 \mathrm{~cm}^{2}$, BNQDs/ILs/GCE's surface area was 0.320 $\mathrm{cm}^{2}$, PtNPs/GCE's was $0.320 \mathrm{~cm}^{2}$ and PtNPs/BNQDs/ILs/GCE had a surface area of $0.752 \mathrm{~cm}^{2}$. Electro surface areas were acquired with $1.0 \mathrm{mM}\left[\mathrm{Fe}(\mathrm{CN})_{6}\right]^{3-}$ solution in which there is also $0.1 \mathrm{M} \mathrm{KCL}$. Equation is as follows: $i_{p}=2.69 \times 10^{5}$ $A n^{3 / 2} D^{I / 2} C v^{1 / 2}$. In that equation $\mathrm{i}_{\mathrm{p}}$ is the current, $\mathrm{C}$ is the concentration of $\left[\mathrm{Fe}(\mathrm{CN})_{6}\right]^{3-}, \mathrm{v}$ is the scan rate and $\mathrm{A}$ is the surface area $\left(\mathrm{cm}^{2}\right)\left(\mathrm{n}=1, \mathrm{D}=7.6 \times 10^{-6}\right.$ $\left.\mathrm{cm}^{2} \mathrm{~s}^{-1}\right)$.

Table 1. Electrochemical parameters of methanol oxidation on modified electrodes (Scan rate: $\left.50 \mathrm{mV} \mathrm{s}^{-1}\right)(\mathrm{n}=6)$

\begin{tabular}{|l|c|c|c|c|c|}
\hline Electrode & $\begin{array}{c}\text { If } \\
\left(\mathbf{A ~ c m}^{-2}\right)\end{array}$ & $\begin{array}{c}\mathbf{E} \\
(\mathbf{V})\end{array}$ & $\begin{array}{c}\mathbf{I b} \\
\left(\mathbf{A ~ c m}^{-\mathbf{2}}\right)\end{array}$ & $\begin{array}{c}\mathbf{E} \\
(\mathbf{V})\end{array}$ & $\mathbf{I f} / \mathbf{I b}$ \\
\hline ILs & $3.1 \pm 0.02$ & 0.92 & $1.82 \pm 0.02$ & 0.73 & 1.77 \\
\hline BNQDs & $4.2 \pm 0.01$ & 0.86 & $2.56 \pm 0.02$ & 0.70 & 1.65 \\
\hline BNQDs/ILs & $8.3 \pm 0.03$ & 0.82 & $3.18 \pm 0.01$ & 0.61 & 2.53 \\
\hline PtNPs/BNQDs/ILs & $10.5 \pm 0.02$ & 0.79 & $4.05 \pm 0.02$ & 0.58 & 2.57 \\
\hline
\end{tabular}

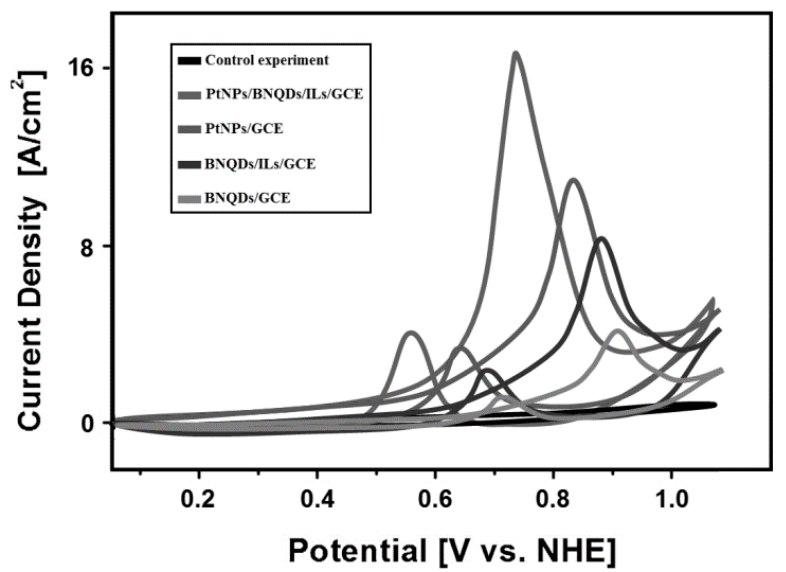

Figure 5. Cyclic voltammograms of $0.5 \mathrm{~mol} \mathrm{~L}^{-1}$ methanol in $0.1 \mathrm{~mol} \mathrm{~L}^{-1}$ $\mathrm{HClO} 4$ at BNQDs/GCE, BNQDs/ILs/GCE, PtNPs/GCE and PtNPs/BNQDs /ILs/GCE

Following chronoamperometry measurements that are shown in Figure 6, steady current status are seen in all electrodes. After the methanol oxidation, various incomplete products adsorbe on the nanmaterials as a result of decaying factor. When we look at the steady-state area, PtNPs/BNQDs/ILs/GCE is the material with the comparatively highest catalytic effect. The results demonstrate that PtNPs/BNQDs/ILs/GCE's usage in methanol oxidation provides a stable electrocatalyst that is tolerant to poisoning.

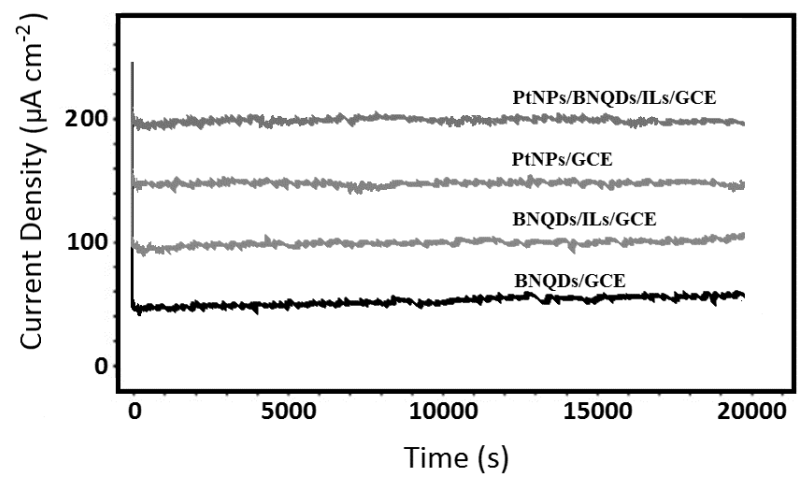

Figure 6. Chronoamperometry results of $0.5 \mathrm{~mol} \mathrm{~L}^{-1}$ methanol in $0.1 \mathrm{~mol} \mathrm{~L}^{-1}$ $\mathrm{HClO} 4$ at BNQDs/GCE, BNQDs/LLs/GCE， PtNPs/GCE，PtNPs/BNQDs $/$ ILs/GCE at $0.6 \mathrm{~V}$ for $20000 \mathrm{~s}$. 
Figure 7 shows a Current-Voltage (I-V) curve that is for a single cell formed with nanomaterials. Cathode's potential changes from a potential of oxygen reduction to a mixed potential. This is caused by the methanol's electro-oxidation caused by cross-over of methanol. PtNPs/BNQDs/ILs nanocomposite usage in fuel cell production provides higher I-V performance compared to other nanomaterials.

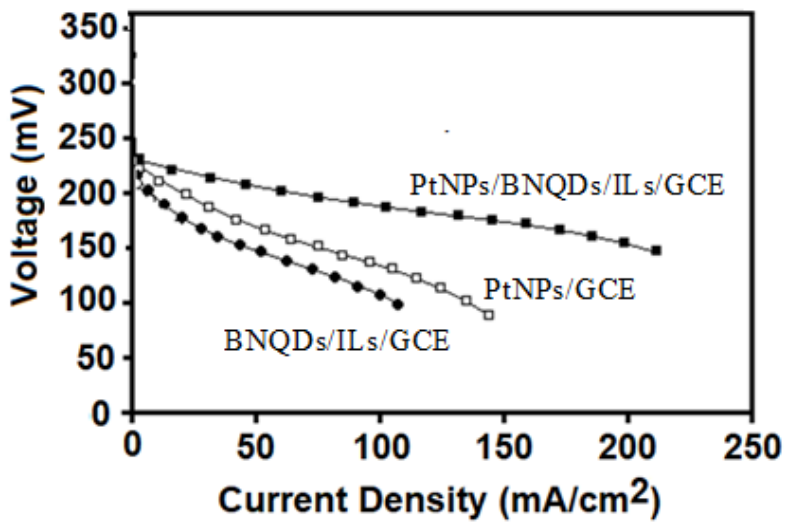

Figure 7. Current-Voltage (I-V) curves of DMFC single cell with the nanocomposite electrodes

Further investigation of oxygen reduction reaction (ORR) activity resulting from different catalyst were performed by carrying outof LSV tests. Results are shown in Figure 8. According to the LSV polarization curves for ORR, ILs have a half-wave potential of $0.80 \mathrm{~V}, \mathrm{BNQDs}$ have a half-wave potential of $0.82 \mathrm{~V}$, BNQDs/ILs have a half-wave potential of $0.87 \mathrm{~V}$ and PtNPs/BNQDs/ILs have a half-wave potential of $0.95 \mathrm{~V}$. Those results have been in $0.1 \mathrm{M} \mathrm{HClO} 4$ environment. It is obvious that ORR activity is comparatively PtNPs/BNQDs/Ils $>$ BNQDs/Ils > BNQDs > ILs. Results of the study show that ORR activity of PtNPs/BNQDs/ILs catalyst is excellent.

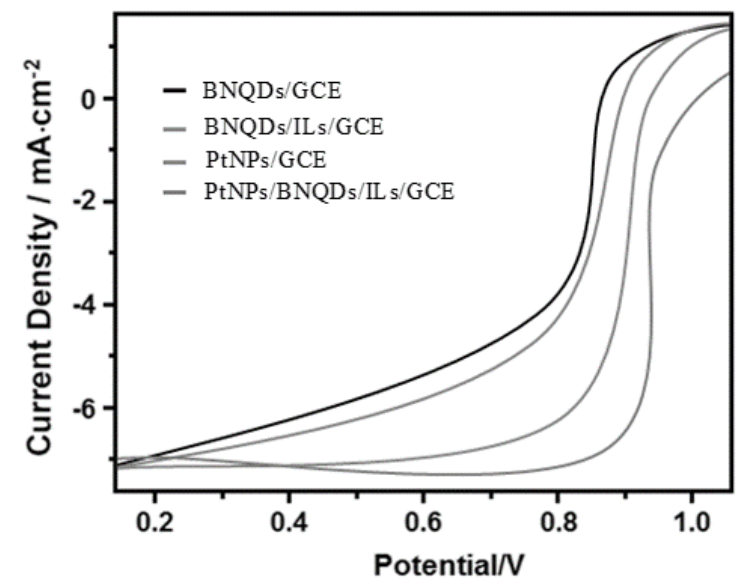

Figure 8. LSV curves of different catalysts at a rotation rate of $1000 \mathrm{rpm}$ in $\mathrm{O}_{2}$-saturated $0.1 \mathrm{M} \mathrm{HClO} 4$ with a scan speed of $100 \mathrm{mV} \cdot \mathrm{s}^{-1}$

\section{CONCLUSION}

In this study, a novel and effective electrocatalyst including platinum nanoparticle (PtNPs)/boron nitride quantum dots (BNQDs)/6-methyl-2-(3hydroxy-4-methoxybenzylidenamino)-benzothiazole (ILs) nanocomposite (PtNPs/BNQDs/ILs) was prepared for DMFCs application. After microscopic, spectroscopic and electrochemical characterizations of PtNPs/BNQDs/ILs composite, the electrocatalytic activities of PtNPs/BNQDs/ILs composite based electrocatalyst towards methanol were evaluated. Especially, novel and promising electrocatalyst that had a large active surface area was prepared. Electro-oxidative activity was high and its tolerance to $\mathrm{CO}$ tolerance was superior for the future DMFCs applications. In addition, electrochemical performance of PtNPs/BNQDs/ILs was compared with other catalysts such as current densities and the forward and backward anodic peak current densities ratio.

\section{REFERENCES}

1. M.H. Habibi, M. Montazerozohori, A. Lalegani, R.W. Harrington, W. Clegg, J. Fluor. Chem. 127, 769-773, (2006)

2. S.A. Abbas, M. Munir, A. Fatima, S. Naheed, Z.E. Ilyas, J. Life Sci. 1, $37-$ 40, (2010).

3. Z. Cimerman, S. Miljanic, J. Antolic, Spectrosc. Lett. 32, 181-196, (1999).

4. R.D. Jones, D.A. Summervile, F. Basolo, Chem. Rev. 79, 139-179, (1979).

5. Ö. Aktaş Yokuş, H. Yüksek, S. Manap, F. Aytemiz, M. Alkan, M. Beytur, Ö. Gürsoy Kol, Bulgarian Chemical Communications, 49 (1), 98-106, (2017).

6. H. Yüksek, B. Göksu, S. Manap, M. Beytur, Ö. Gürsoy Kol, Chemical Science International Journal, 22 (2), 1-29, (2018).

7. T.M.A. IsmailJ. Coord. Chem. 58 (2), 141-151, (2005).

8. M.T.H. Tarafder, N. Saravanan, K.A. Crouse, A.N. Ali, Trans. Met. Chem. 26, 613-618, (2001).

9. Ş. Bahçeci, N. Yıldırım, S. Manap, M. Beytur, H. Yüksek, Rasayan journal of chemistry, 9 (3), 494-501, (2016).

10. C.A. Mc Auliffe, R.V. Parish, S.M. Abu-El-Wafa, R.M. Issa, Inorg. Chim Acta. 115, 91-94, (1986).

11. S. Zolezzi, E. Spodine, A. Decinti, Polyhedron 21, 55-59, (2002).

12. V. Ambike, S. Adsule, F. Ahmed, Z. Wang, Z. Afrasiabi, E. Sinn, F. Sarkar, S. Padhye, J. Inorg. Biochem. 101, 1517-1524, (2007).

13. M.I. Mejeha, M.C. Nwandu, K.B. Okeoma, L.A. Nnanna, M.A. Chidiebere, F.C. Eze, E.E. Oguzie, J. Mater. Sci. 47, 2559-2572, (2012).

14. A.A. Abdel Aziz, J. Lumin. 143, 663-669, (2013).

15. W. Al Zoubi, N.D. Al Mohanna, Spectrochim. Acta A, 132, 854-870, (2014).

16. S. Andres, P. Guarin, S. Dufresne, D. Tsang, A. Sylla, W.G. Skene, J. Mater. Chem. 17, 2801-2807, 2007.

17. S. Di Bella, I.P. Oliveri, A. Colombo, C. Dragonetti, S. Righetto, D. Roberto, Dalton T. 41, 7013, (2012).

18. S. Kumar, D.N. Dhar, P.N. Saxena, J. Sci. Int. Res. 68, 181, 2009.

19. N.M. Hosnya, M.A. Hussiena, F.M. Radwana, N. Nawar, Spectrochim. Acta A, 132, 121-129, (2014).

20. D. Sek, A. Iwan, B. Jarzabek, B. Kaczmarczyk, J. Kasperczyk, Z. Mazurak, M. Domanski, K. Karon, M. Lapkowski, Macromolecules, 41, 6653, (2008).

21. A. Zabulica, M. Balan, D. Belei, M. Sava, B.C. Simionescu, L. Marin, Dyes Pigm. 96, 686, (2013).

22. F. Azam, S. Singh, S.L. Khokhra, O. Prakash, J. Zhejiang, Univ. Sci. B. 8, 446-452, (2007).

23. P. Przybylski, A. Huczynski, K. Pyta, B. Brzezinski, F. Bartl, Cur. Org. Chem. 13, 124, (2009).

24. S. Amer, N. El-Wakiel, H. El-Ghamry, J. Mol. Struct. 1049, 326-332, (2013).

25. I. Kraicheva, I. Tsacheva, E. Vodenicharova, E. Tashev, T. Tosheva, A. Kril, M. Topashka-Ancheva, I. Iliev, T.S. Gerasimova, K. Troev, Bioorg. Med. Chem. 20, 117-124, (2012).

26. S.D. Khanye, J. Gutb, P.J. Rosenthal, K. Chibale, Gregory S. Smith, J. Organomet. Chem. 696, 3296-3300, (2011).

27. A.M. Alafeefy, M.A. Bakht, M.A. Ganaie, M.N. Ansarie, N.N. El-Sayed, A.S. Awaad, Bioorg. Med. Chem. Lett. 25, 179-183, (2015).

28. B. Vivekanand, K.M. Raj, B.H.M. Mruthyunjayaswamy, J. Mol. Struct. 1079, 214-224, (2015).

29. Z. Beigi, A.H. Kianfar, H. Farrokhpour, M. Roushani, M. H. Azarian, W.A. K. Mahmood, J. Mol. Liq. 249, 117-125, (2018).

30. H. Jafar, M. Neda, R. Mahmoud, M. Leila, B. Mehrangiz, R. Mehdi, Dalton Trans. 42 (34), 12364-12369, (2013).

31. H. Jafar, B. Zahra, B. Mehrangiz, R. Mahmoud, R. Mehdi, J. Organomet. Chem. 769, 1-6, (2014).

32. M.S. Faber, S. Jin, Energ. Environ. Sci. 7, 3519-3542, (2014)

33. S. Khadempir, A. Ahmadpour, M.T .Hamed Mosavian, N. Ashraf, F.F. Bamoharram, R. Fernandez-Pacheco, J.M. de la Fuente, S.G. Mitchell, RSC Adv. 6, 5359-5366, (2016).

34. R. Liu, G. Zhang, H. Cao, S. Zhang, Y. Xie, A. Haider, U. Kortz, B. Chen, N.S. Dalal, Y. Zhao, L. Zhi, C.-X. Wu, L.-K. Yan, Z. Su, and B. Keita, Energ. Environ. Sci. 9, 1012-1023, (2016).

35. J. Lu, L. Hong, Y. Yang, S. Xu, S.Wang, J. Yuan, L. Niu, J. Nanopart. Res. 16, 2162-2168, (2014)

36. M. Rashid, T.-S. Jun, Y. Jung, Y. S. Kim, Sensor Actuat. B-Chem. 208, 7 13, (2015).

37. M.L. Yola, N. Atar, J. Electrochem. Soc. 165 (14), 897-902, (2018)

38. Q. Weng, B. Wang, X. Wang, N. Hanagata, X. Li, D. Liu, X. Wang, X. Jiang, Y. Bando, D. Golberg, ACS. Nano. 8 (6), 6123-6130, (2014).

39. A.F. Khan, D.A.C. Brownson, E.P. Randviir, G.C. Smith, C.E. Banks, Anal. Chem. 88 (19), 9729-9737, (2016). 
40. N. Atar, M.L. Yola, J. Electrochem. Soc. 165 (5), 255-262, (2018).

41. Y. Ide, F. Liu, J. Zhang, N. Kawamoto, K. Komaguchi, Y. Bando, D. Golberg, J. Mater. Chem. A, 2 (12), 4150 (2014).

42. L. Hongling, T.R. Yingjie, T.S. Hon, Z. Xu, T.E.H. Tong, Small, 11 (48), 6491-6499, (2015).

43. M. Ramuz, A. Hama, M. Huerta, J. Rivnay, P. Leleux, R.O. Qwens, Adv. Mater. 26 (41), 7083-7090, (2014).

44. Z. Lei, S. Xu, J. Wan, P. Wu, Nanoscale, 7 (45), 18902-18907, (2015).

45. L. Mengli, X. Yuanhong, W. Yao, C. Xu, J. Xuqiang, N. Fushuang, S. Zhongqian, L. Jingquan, Adv. Opt. Mater. 5 (3), 1600661, (2017).

46. F. Baştürk, H. Yüksel, R. Solmaz, Int. J. Hydrog. Energy. 44, 14235-14242, (2019).

47. A. T. Çolak, T. Eren, M.L. Yola, E. Beşli, O. Şahin, N. Atar, J. Electrochem. Soc. 163 (10), F1237-F1244, (2016).
48. O. Akyıldırım, G. Kotan, M.L. Yola, N. Atar, Ionics. 22 (4), 593-600, (2016).

49. N. Atar, T. Eren, B. Demirdögen, M.L. Yola, M.O. Çağlayan, Ionics. 21 (8), 2285-2293, (2015).

50. N. Atar, T. Eren, M.L. Yola, H.K. Maleh, B. Demirdögen, RSC Advances. 5 (33), 26402-26409, (2015).

51. M.L. Yola, N. Atar, Z. Üstündağ, A.O. Solak, J. Electroanal. Chem. 698, 916, (2013).

52. N. Atar, M.L. Yola, J. Electrochem. Soc. 164, 223-229, (2017).

53. L.H. Li, Y. Chen, B.M. Cheng, M.Y. Lin, S.L. Chou, Y.C. Peng, Appl. Phys. Lett. 100, 261108, (2012).

54. L.H. Li, Y. Chen, G. Behan, H. Zhang, M. Petravic, A.M. Glushenkov, J. Mater. Chem. 21, 11862-11866, (2011). 